\title{
Effect of Interspecific Competition between the Larger Grain Borer, Prostephanus truncatus (Horn) (Coleoptera: Bostrychidae) and the Maize Weevil, Sitophilus zeamais (Motschulsky) (Coleoptera: Curculionidae) on Grain Damage and Progeny Production in Stored Maize (Zea mays L)
}

\author{
*SADIKU. B.T., KEMABONTA, K.A., AND MAKANJUOLA, W. A. \\ Department of Zoology, University of Lagos, Akoka -Yaba, Lagos, \\ Lagos State, Nigeria
}

Nig. J. Entomol. 33:37-45(2017)

ABSTRACT: This study investigated the effect of the interaction between Prostephanus truncatus(Horn)(LGB) and Sitophilus zeamais (Motschulsky) (MW) on grain damage and progeny production in stored maize. $50 \mathrm{~g}$ maize grains replicated four times was placed into $250 \mathrm{ml} \mathrm{Kilner}{ }^{*} .10$ and 5 pairs of $1-3$ day old adult LGB and MW were introduced into each Kilner ${ }^{8}$ jar in single and simultaneous infestation and placed in a completely randomized design (CRD) in the laboratory at $27 \pm 1^{\circ} \mathrm{C}$ and $75-80 \% \mathrm{RH}$. There was increase in the number of emerged insects from $\mathrm{F} 1$ to $\mathrm{F} 2$ for both insects. The percentage change in the number of emerged LGB was $18.7 \%$ and $9.0 \%$ in single and simultaneous infestation respectively, while in $\mathrm{MW}$, it was $13.2 \%$ and $16.8 \%$ respectively. There was a significant reduction in the reproductive performance of the two insects during simultaneous infestation when compared with single infestation The weight loss and damage caused by LGB were 4.31 and $7.21 \%$ while that for $\mathrm{MW}$ were 2.55 and $5.85 \%$ respectively for single infestation and 5.0 and $9.67 \%$ for simultaneous infestation at F1. For F2 generation weight loss and damage to grains was 6.90 and $11.14 \%$ for LGB and 3.78 and $7.79 \%$ for MW during single infestation while for simultaneous infestation it was 8.33 and $13.33 \%$. There was a positive correlation between the number of LGB and MW and the grain weight loss and weight damage of stored maize. The result of the study indicated the potential of LGB and MW to eause huge weight loss and damage in maize grains which can lead to serious storage losses.

Keywords: Prostephanus truncentus. Sitophilus ze'uncuis, grain damage, reproductive performance, grain weight loss.

\section{INTRODUCTION}

Insect pest damage to store grains result in majoreconomic losses to farmers throughout the world (Obeng-Ofori. 20(08). It is estimated that approximately one-third of the world food crop is destroyed by insects at various stages including storage. This constitutes a major constraint to

*Corresponding author:

E-mail: cnitimi(ugmail.com food security and income generation in subSaharan Africa (Abebe et al., 2009: Osipitan et (11.. 2011). Up to 2()-30\%, loss of maire can be experienced because farmers often lack effective post-harrest storage technologies (Mwokolo el (al. 2012) especially in rural regions where maize is rypically stored in bags other containers (Abass al al. 2014. De Grout e't al., 2013), and these losses are due primarily to two internally feeding postharvest insect pests namely, maize 
weevil (MW) Sitophilus zecincris (Motschulsky) and the larger grain borer (LGB) Prostephanus trunccitus (Horn) (Omondi e't al., 2011: Teferat et al.. 2011). Prostephanus trunceatus and S. zeancais are primary insect pests of miaze (Meikle et al., 1998) resulting in screre damage and great weight losses in stored maize. Once the crop has attained maturity and is drying in the field, both insects infest the standing crop but most damages occur in storage. The insects cause characteristic damage to maize by making holes in which the adult female deposit her eggs on the grain. Being internal feeders, early detection of infestation by these insects is very difficult (Sahaf et al., 2008). The damages caused result directly in loss of food (reduced grain weight) ready for consumption or loss of cash from farmers' pocket ready to buy other valuable resources for the family (Boxall et al., 2002). The damage also reduces the viability of the seeds (Cornelius et al., 2008) as the larvae and adult consume the embryo affecting maize production of farmers who plant grains of the last season as seed. Apart from the physical damage, there is also the health risk associated with the consumption of infested maize kernels as it has been reported to have relatively higher levels of aflatoxin contamination than non-infested maize kernels (Dhliwayo and Pixley, 2003, Golob, 2002, Kankolongoet al.,2009).

The LGB is rated as the most damaging postharvest insect pest of maize causing substantial losses and aggravating hunger and poverty (Nwololo et al., 2010). Larger Grain Borer and MW are known to complete their development over a wide range of temperature, ranging from $27^{\circ} \mathrm{C}$ to $32^{\circ} \mathrm{C}$ and between $70 \%$ and $80 \%$ relative humidity conditions. The developmental period for both insects is approximately 30 days (Howard, 1984). The intrinsic rate of increase of LGB is reported by Cowley et al., (1980) to be Lambda 1.399 at optimum conditions on shelled maize grains and this apparently low rate may reflect a feature of inter-specilic competition with more fecund storage pests like $S$. zeancis. It is therefore important to examine the interaction of LGB and S. zecamcis from this point of view. As noted by Chapman and Resiss (2002), organisms differ in their ability to compete with each other and hence varying impacts of one species on another. Regarding inter-specific associations, Weimerskirch et al.. (20)3) observed that these can cause changes in reproduction since the effect of increasing intensity of competition among adult insects decreases fecundity or rate of reproduction after some generations. The objective of this study therefore, was to compare the F1 and F2 adults that emerged during single and simultaneous infestation as well as the damage and weight loss caused by the infestation of these insects in stored maize.

\section{MATERIALSAND METHODS}

\section{Insect Culture}

Prostephamus truncatus (LGB) and Sitophilus zeamais were obtained from a culture maintained on dried maize grains in separate $250 \mathrm{ml} \mathrm{Kilner}^{\mathrm{E}}$ jars in the Entomology Research Laboratory of the Department of Zoology, Faculty of Science, University of Lagos. Several LGB and Sitophilus zeamais adults were introduced separately into the uninfested maize grains. For massive production of the two insect pests, Sitophilus zeanais was reared on shelled maize while LGB was reared on maize on the cobs (Hodges 1986, Kossou et al., 1992). Frass generated by the feeding activities of the insects were sieved out on weekly basis using sieve of mesh size $0.25 \mathrm{~mm}$ to prevent excessive grain moisture content and growth of mould. The jars were left undisturbed and emerged $\mathrm{Fl}$ adults were collected into vials containing disinfested maize grains.

\section{Assessment of F1 and F2 P. truncatus and $S$. zeanais Numbers}

The maize variety (Oba-Super 1 ) used for the study was obtained from the Crops Sub-Component of the Lagos State Agricultural Development Authority, Oko-Oba, Agege(LSADA). The maize grains were picked to remove unwholesome ones and disinfested by keeping them in the freezer at 20" (cold shocking) for ten days and then laving them on the laboratory bench for 10 days to attain equilibrium condition of temperature and relative humidity $\left(27 \pm 1^{\circ} \mathrm{C}\right.$ and $\left.75-80^{\circ}, 0 \mathrm{RH}\right)$. Thereafter, $50 \mathrm{~g}$ maize grains were weighed into $250 \mathrm{ml}$ Kilner" jars and infested with 1-3 day old adult 
LC JB and S. =ermais. Therewere four treatments replicated four times and arranged in the laboratory in a Completely Randomized Design (CRD) as follows:

i. Single infestation of maize grains with 10 pairs of LGB.

ii. Single infestation of maize grains with 10 pairs of S. zecanciis.

iii. Simultaneous infestations of maize grains with 5 pairs of LGB and 5 pairs of MW.

iv. Control comprised only maize grains without insects, this serves to measure moisturegainor loss as a result of environmental factors.

All the treatments and control were replicated four times. After 7 days the adults were removed from each replicate, and left undisturbed for 13 days for $F 1$ generation. Thereafter, the grains were inspected daily for emergence of $\mathrm{F} 1$ adults. Adults that emerged were removed and numbers recorded. The exercise continued until no adult emerged for three days. Similarly, a number of dead insects was also recorded. In the separate set ups for the F2 generation, FI adults were left to mate and lay eggs in the maize samples for two weeks and the F2 adults were then removed and recorded as they emerged.

\section{Determination of Grain Damage and Weight Loss of Maize Grains}

At 70 days after infestation, each sample replicate was sieved to remove the resultant maize dust, and weighed to determine the weight losses of the maize grains at both FI and F2. Damage was assessed after the complete emergence of adult insects. This was done by separating grains into damaged and undamaged grains and calculating percentage damage according to Baba-Tieto (1994) and Adedire and Ajavi (1996). The actual weight loss $(\%)$ of the mais grains due to insect attack and grain damage $(\%)$ were calculated according to BabaTieto (1994) and Yusuf and Ahmed (2005) using the formula:

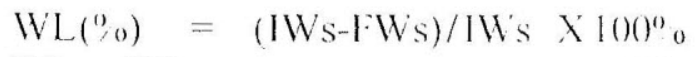
WhereWL $=$ Weight

loss

IWs = Initial weight of sample before

infestation

Fws $=$ Finalweight sample after infestation

$\mathrm{GD} \%=\mathrm{WD} / \mathrm{TW} \times 100 \%$

Where GD $=$ Grain damage

WD $\quad=$ Weight of damage grains

TW = Totalweight of damage and undamaged grains

\section{Data Analysis}

Data were subjected to analysis of variance (ANOVA) and means were separated using Duncan's New Multiple Range Test (DNMRT) at $p<0.05$. The t-test was carried out to compare the changes in the numbers of emerged F1 and F2 progeny of $P$. truncatus and $S$. zecamais and their mortality during single and simultaneous infestation. Damage indices for both F1 and F2 of the two insects were correlated using SPSS software.

\section{RESULTS}

\section{Number of Emerged Adult LGB and S. zeanais}

The results showed different reproductive performances of the two insects during single and simultaneous infestation in maize grains. The mean number of emerged LGB and Sitophilus zeamais at F1 and F2 is shown in Table 1. In the $\mathrm{F} 1$ generation, the mean number of $S$. zeamais that emerged (174) during single infestation was signiticantly higher $(p<0.05)$ than the number of emerged LGB (109). Similarly, for the simultaneous infestation, the number of emerged S. zeamais (99) was significantly higher $(\mathrm{p}<0.05)$ than the number of LGB (77). Same trend were obtained in $\mathrm{F} 2$ generation.

There was a change in adult insect numbers from $\mathrm{Fl}$ to $\mathrm{F} 2$ for the two insects. The result indicated that there is a significant increase in the numbers of emerged LGB and $S$. zemmais during single and simultaneous infestation at both $\mathrm{Fl}$ and F2 respectively. Each insect exhibited higher but not significant number of emergence from $\mathrm{F} 1$ to F2. The percentage change in numbers of LGB during single infestation (18.7) was greater than during simultaneous infestation(9.0)(Table 1) when 
Table 1: Nean number of adult insects that emerged and change (\%) in adult numbers from F 1 to $\mathrm{F} 2$ in single and simultancous infestation

\begin{tabular}{lllll}
\hline Insect spp & $\begin{array}{l}\text { Infestation } \\
\text { Type }\end{array}$ & F1 & F2 & \% Change \\
\hline P. truncutus & Single & $109.0 \pm 15.6^{\mathrm{b}}$ & $169.0 \pm 73.7^{\mathrm{c}}$ & $18.7 \pm 14.7^{\mathrm{c}}$ \\
& Simultaneous & $77.0 \pm 21.5^{-\mathrm{a}}$ & $92.0 \pm 23.1^{\mathrm{i}}$ & $9.0 \pm 3.0^{\mathrm{a}}$ \\
\multirow{3}{*}{ S. zecancis } & Single & $174.0 \pm 67.3^{\mathrm{c}}$ & $223.0 \pm 68.5^{\mathrm{d}}$ & $13.2 \pm 3.7^{\mathrm{b}}$ \\
& Simultaneous & $99.0 \pm 1.7^{\mathrm{b}}$ & $125.0 \pm 52.7^{\mathrm{b}}$ & $16.8 \pm 10.3^{\mathrm{b}}$ \\
\hline
\end{tabular}

Means followed by the same letter in each column are not significantly different $(\mathrm{P}<0.05)$ according to Duncan New Multiple Range Test (DNMRT).

Weight and Damage Assessment During Single and Simultaneous Infestation of LGB and MW

There was an increase in the damage and weight loss of grains from F1 to F2 (Table 2). The mean weight of dust, weight loss and grain damage increased significantly from $F 1$ to $F 2$ during single and simultaneous infestation for the two insects. The weight loss and grain damage caused by LGB was significantly higher $(\mathrm{P}<0.05)$ than that caused by $S$. zeamais under similar conditions. In single species infestation at both $F 1$ and F2, significantly higher $(p<0.05)$ maize damage was caused by LGB (7.21 and $11.4 \%$ ) compared to S. zeamais (5.85 and $7.79 \%$ ). Weight loss on the other hand was (4.31 and $6.90 \%)$ as well as $(2.55$ and $3.78 \%)$ respectively, for LGB and MW. Weight loss (5.0 and $8.33 \%$ ), and grain damage (9.67 and $13.33 \%$ ) recorded during simultaneous infestation was significantly higher $(p<0.05)$ when compared with the values recorded during single infestation of the individual insect. The mean weight of dust recorded during single infestation of the individual insect ( 2.39 and $3.63)$ and (1.43 and 2.40) though significantly high $(\mathrm{p}<0.05)$ is not as high as the dust recorded during simultaneous infestation of both insects (4.03 and 4.67) at both F1 and F2.

\section{Mortality of Adult Prostephanus truncatus} and Sitophilus zeamais at F1 and F2

Mortality of LGB was significantly higher $(\mathrm{p}<0.05)$ at both F1 and F2 than the mortality recorded from $S$. zeamais during single and simultaneous infestation(Table 3 ).

\section{Correlation of LGB and Sitophilus zeamais and the Damage Indices at F1 and F2}

The correlation of the cight of dust, weight loss and damage was sign positive $(p<0.05)$ (Tables $4 \& 5$ ) during single infestation for both LGB and $S$. zeamais at both F1 and F2. Same trend occurs in simultaneous infestations (Table 6) for the two insects.

Table 2: Mean Weight (Wt) of dust, \% Weight loss and \%Grain damage at F1 \& F2

\begin{tabular}{|c|c|c|c|c|}
\hline Insect spp & Infestation type & Dust & $\%$ Wcight loss & $\%$ Grain damage \\
\hline P.truncatus & Single $(F \mid)$ & $2.39 \pm 0.63^{b}$ & $+.31 \pm 1.12^{\circ}$ & $7.21 \pm 3.13^{b}$ \\
\hline \multirow[t]{2}{*}{ S. zeamais } & Single $(F 1)$ & $1.43 \pm 0.29^{\mathrm{a}}$ & $2.55 \pm 0.81^{\mathrm{a}}$ & $5.85 \pm 2.33^{\mathrm{a}}$ \\
\hline & Simultaneous( $\mathrm{F} \mid$ ) & $+.03+1.18^{\mathrm{i}}$ & $5.00 \pm 1.73^{\mathrm{d}}$ & $9.67 \pm 3.48^{\circ}$ \\
\hline P.truncutus & Single $(F 2)$ & $3.63 \pm 1.38^{\circ}$ & 6.9()$\pm 1.07^{\circ}$ & $11.1+ \pm 2.60^{\mathrm{d}}$ \\
\hline \multirow[t]{2}{*}{ S. zeamais } & Single(F2) & $2.40+0.84^{\mathrm{b}}$ & $3.78 \pm 0.900^{\mathrm{b}}$ & $7.79+2.63^{\mathrm{b}}$ \\
\hline & Simultaneous $(\mathrm{F} 2)$ & $4.67 \pm 1.45^{d}$ & $8.33 \pm 3.76^{\circ}$ & $13.33 \pm 3.76^{\circ}$ \\
\hline
\end{tabular}

Means followed by the same letter in each column are not significantly different (P 0.05$)$ according to Duncan New Multiple Range Test (I)NMRT). 
Table 3: Nortality of Adult LGB and Sitophilus zeamais at F1andF2

\begin{tabular}{|c|c|c|c|}
\hline Insect spp & Infestation type & LGB & S. zeamais \\
\hline P.truncentus & Single(Fl) & $4.31 \pm 1.12^{c}$ & $2.39 \pm 0.63^{b}$ \\
\hline S. zecumais & Simultancous $(F 1)$ & $2.55 \pm 0.81^{\mathrm{a}}$ & $1.43 \pm 0.29^{: 1}$ \\
\hline P.truncuths & Single(F2) & $5.00+1.73^{d}$ & $4.03+1.18^{d}$ \\
\hline S. zcetmais: & Simultancous (F2) & $6.90 \pm 1.07^{\mathrm{a}}$ & $3.63 \pm 1.38^{\circ}$ \\
\hline
\end{tabular}

Means followed by the same letter in each column are not significantly different $(\mathrm{P}<0.05)$ according to Duncan New Multiple Range Test (DNMRT).

Table 4: Correlation matrix of Prostephanus truncutus and damage indices at F1 and F2 (single infestation)

\begin{tabular}{lllllll}
\hline & $\begin{array}{l}\text { F1 } \\
\text { DUST }\end{array}$ & $\begin{array}{l}\text { F1 } \\
\text { LOSS }\end{array}$ & $\begin{array}{l}\text { F1 } \\
\text { DAMAGE }\end{array}$ & $\begin{array}{l}\text { F2 } \\
\text { DUST }\end{array}$ & $\begin{array}{l}\text { F2 } \\
\text { LOSS }\end{array}$ & $\begin{array}{l}\text { F2 } \\
\text { DAMAGE }\end{array}$ \\
\hline F1 DUST & 1 & & & & & \\
F1 LOSS & $0.000^{* *}$ & 1 & & & & \\
F1 DAMAGE & $0.000^{* *}$ & $0.000^{* * *}$ & 1 & & & \\
F2 DUST & $0.000^{* *}$ & $0.000^{* * *}$ & $0.000^{* * *}$ & 1 & & \\
F2 LOSS & $0.000^{* * *}$ & $0.000^{* * *}$ & $0.000^{* * *}$ & $0.000^{* *}$ & 1 & \\
F2 DAMAGE & $0.000^{* *}$ & $0.000^{* *}$ & $0.000^{* * *}$ & $0.000^{* *}$ & $0.000^{* *}$ & 1 \\
\hline
\end{tabular}

Correlation is significant at the $0.01 \mathrm{level}$

Table 5: Correlation matrix of Sitophilus zeanais and damage indices at F1 and F2 (single infestation)

\begin{tabular}{lllllll}
\hline & F1 & F1 & F1 & F2 & F2 & F2 \\
& DUST & LOSS & DAMAGE & $\begin{array}{l}\text { DUST } \\
\text { LOSS }\end{array}$ & DAMAGE \\
\hline F1 DUST & 1 & & & & & \\
F1 LOSS & $0.26^{*}$ & 1 & & & & \\
F1 DAMAGE & $0.26^{*}$ & $0.000^{* *}$ & 1 & & & \\
F2 DUST & $0.26^{*}$ & $0.000^{* *}$ & $0.000^{* * *}$ & 1 & & \\
F2 LOSS & $0.26^{*}$ & $0.000^{* *}$ & $0.000^{* * *}$ & $0.000^{* * *}$ & 1 & \\
F2 DAMAGE & $0.26^{* *}$ & $0.000^{* *}$ & $0.000^{* *}$ & $0.000^{* *}$ & $0.000^{* *}$ & 1 \\
\hline
\end{tabular}

Correlations are significant at $0.0 \mathrm{I}$ and 0.05 levels

Table 6: Correlation Matrix of Both Sitophilus zeamais and Prostephanus truncatus at F1 and F2 (Simultaneous Infestation)

\begin{tabular}{|c|c|c|c|c|c|c|}
\hline & $\begin{array}{l}\text { F1 } \\
\text { DUST }\end{array}$ & $\begin{array}{l}\text { F1 } \\
\text { LOSS }\end{array}$ & $\begin{array}{l}\text { F1 } \\
\text { DAM } A \text { GE }\end{array}$ & $\begin{array}{l}\text { F2 } \\
\text { DUST }\end{array}$ & $\begin{array}{l}\text { F2 } \\
\text { LOSS }\end{array}$ & $\begin{array}{l}\text { F2 } \\
\text { DAMAGE }\end{array}$ \\
\hline F1 DUST & 1 & & & & & \\
\hline F1 LOSS & 0.000 & 1 & & & & \\
\hline F1 DAMAGE & $0.000^{* *}$ & $0.0000^{20}$ & 1 & & & \\
\hline F2 DUST & $0.0000^{* \%}$ & $0.000^{* * *}$ & $0.000^{* * 3}$ & 1 & & \\
\hline F2 LOOSS & 0.000 & $0.000^{\circ}$ & 0.000 & $0.00(0)^{* *}$ & 1 & \\
\hline F2 DAMAGE & $0.000^{6 *}$ & $0.0000^{* *}$ & 0.000 & $0.000^{* * 3}$ & $0.000^{* * *}$ & 1 \\
\hline
\end{tabular}

Correlation is significant at the 0.01 level

\section{DISCUSSION}

The results showed the different reproductive performance of the two insects at four different treatment levels. Inter specific competition is normally more frequent and symmetrical among species feeding internally than among species feeding externally. Competition generally is assumed to have only negative effects on both (all) competing species. Competitions among individuals of a given population represent a 
major negatic feedback mechanism for regulation of population size. Similarly, competitions among species represent a majormechanism for regulations of the total abundance of multiple species populations. It was deduced from the study that as the number of LGB and MW increased, each individual had access to a decreasing share of the resource(s) and since the competition is asymmetrical, the superior species (MW) completely suppressed the population of LGB.

It was noted from the study that MW produced more individuals at F1 and F2 than LGB. However, the number of progeny from both species was adversely affected by competitive interactions. As noted by Chapman and Reiss (2002) organisms differ in their ability to compete with each other and hence varying impacts of one species on another. Regarding inter-specific associations, Weimerskirch et al (2003) observed that these can cause changes in reproduction since the effect of increasing intensity of competition among adult insects decreases fecundity or rate of reproduction after some generations. Mortality of adult LGB was higher than that of MW during simultaneous infestation at both F 1 and F2 generations. This is an indication that MW was the dominant competitor and had a significant suppressant effect on the activities of $P$. truncatus when in interspecific competition. As reported by Denno et al., (2002) most competitive interactions were asymmetrical that is, one species is a superior competitor and suppressed the other.

The study revealed that $S$. zeamais would out-compete $P$. truncatus when they are both present together on shelled maize. This is in consonance with the report of Golob (1988) that S. zeamuis thrives well on loose grains relative to LGB that thrives well on unshelled maize.

Dust production by $P$. truncatus during single and simultancous infestation at both $\mathrm{Fl}$ and $\mathrm{F} 2$ exceeded that of $S$. zeamciis. This is attributable to the extensive tunneling of the grain by $P$. truncutus. This tumneling by $P$. truncatus allows it to convert grains into flour within a very short period of time. This corroborates the position of Hodges et al (1983) that the most obvious cause of weight loss in $P$. truncatus infested grain is the conversion of the grain to maize pow der by the boring activities of both larvae and adults. The mean weight losses $(4.31 \%$ and $6.90 \%),(2.55 \%$ and $3.78 \%)$ and the damage $(7.21 \%$ and $11.14 \%$ \%). $(5.85 \%$ and $7.79 \%)$ recorded for $P$. truncertus and $S$. zeemeris (single infestation at both $\mathrm{F} 1$ and $\mathrm{F} 2$ ) during the course of the study implies that post harrest losses due to the two insects could be severe if adequate control measures are not put in place. The results reported here is consistent with those of earlier workers who reported that grain losses in maize caused by MW are $12-20 \%$ and $9-45 \%$ for $L G B$ depending on periods of storage (Abdullahict al., 2011, Gueye et al., 2008, Law-Ogbomo and Enobakhare, 2006, Markharm et crl., 1991: Panthenius, 1988, Tefera et al., 2011). Similarly in Malawi, Singano et al., (2007) reported that after the introduction of $P$. rruncatus, harvested maize grain losses was up to $80 \%$ on shelled maize after six months. In very intense cases of infestation, the stored maize can practically be completely destroyed; resulting in total loss (Singano and Nkhata, 2004). Another reason that can be adduced for such danage could be that the two insects have mouthparis that are well adapted for chewing and grinding of maize grains into powder.

The final insect de ities, grain damage, dust produced and weigl loss for $P$. truncatus exceeded that of $S$ zeamais during single infestation. Greater lamage and weight loss recorded in grain infested with LGB than those infested with MW was not unexpected considering the tact that LGB has been widely reported to be the most destructive insect pest of contemporary times (Anankwara of al.. 2012. Omondi et al.. 2011). The insect was noted to cause losses that exceeded those of other insects under similar conditions (GASGA, 1993). Storage losses in LGB-infested maize according to ADA (2010) varied between $15 \%$ and $30 \%$ depending on the regions. This agrees with the work of (jolob and Hodges (1982) who reported that in Tanzania. the introduction of I.GB elevated maize losses in store to $50^{\circ}$, from the previous arerage of $5 \%$ damage. According to Magrath et al., (1996). loss in maize due to $P$. truncatus was consistently higher than those due to other insect pest species. Although many 
storage insect pests are ubiquitous throughout the sub-Saharan Africa, P. truncatus has been found to cause more than twice the weight loss in maize than infestation by $S$. zeamais (Stathers et al., 2008)

\section{CONCLUSION}

It can be concluded that simultaneous infestations significantly reduced the reproductive performance of LGB and S. zeamais at both F1 and F2 generations. The result also revealed the ability of $S$. zeamais to suppress the activities of LGB when in competitive interaction. The result of the study indicates the potential of LGB and $S$. zeamais to cause huge weight loss and damage maize grains leading to serious storage losses. These losses and damage can result in food insecurity, threat to the livelihood of the poor people in Africa as well as health risk associated with the consumption of infested maize kernel, as it has been reported to have relatively high levels of aflatoxin contamination than non-infested maize kernels (Dhliwayo and Pixley, 2003; Kankolongo et al., 2009). Considering the importance of maize as a major staple food crop in Africa, concerted effort should therefore be geared toward controlling the infestation of maize grain by LGB and $S$. zeamais.

\section{ACKNOWLEDGEMENT}

The authors appreciate Crops Development SubComponent of the Lagos State Agricultural Development Authority (LSADA), Oko-Oba, Agege, for providing the maize variety used for the study.

\section{REFERENCES}

Abbas, S., Ahmed, I., Kudo, T., Iida, T., Ali, G. N., Fujiwara, T. and Ohkuma, M. (2014). Heary metal-tolerantand psychrotolerant bacterium Acinetohacter pakistanensis isolated from a textile dyeing waste water treatment pond. Pakistani Journal Agricultural Science, 51:593-606.

Abebe, F., Tefera, T., Mugo, S., Beyene, Y. and Vidar, S. (2009). Resistance of maize varieties to the maize weevil Sitophilus zeamais (Motsch) (Coleoptera: Curculionidae). Africa Journal of Biotechnologe 8:5937-5943.

Abdullahi, N., A. Kabir and Yushau, M. (2011). Studies on the efficacy of lime peel oil in protecting stored maize against adult maize weevils (Sitophilus zeamais Motschulsky). Jounal of Entomologi; 8:398-403.

ADA (2010). Consulting Etude de Falsibilite du System de Warrantage des Products Agricoles Cereallers dans les Departments du zou/ Collines/Borgou/Alibori, Mono/Couffo et Oueme/Plateau. Final Report (Cotonou, Benin).

Adedire, C.O. and Ajayi, T.S.(1996). Assessment of the insecticidal properties of some plant extracts as grain protectants against the maize weevil, Sitophilus zeamais Motschulsky. Nigerian Jounal of Entomologn: 13:93-101.

Anankwara, P. J., Ansah, A.F., Fatunbi, A.O., Afreh-Nuamah, K. and Obeng-Ofori, D. (2012). Efficacy of the multiple layers hermetic storage bag for biorational management of primary beetle pests of stored maize. Academic Journal of Entomology, 5:47-53.

Baba-Tierto, N. (1994). Ability of powders and slurries from ten plant species to protect stored grains from attack by Prostephanus truncatus (Hom) (Coleoptera: Bostrichidae) and Sitophilus oryzae(L)(Coleoptera:Curculionidae).Jotrnal of StoredProduct Research, 30:297-30.

Boxall, R.A., Brice, J.R., Taylor, S.J. and Bancroft, R.D. (2002). Technology and Management of Storage. Crop Post-Harvest: Science and Technology; Principles and Practices Vol. 1. Blackwell, London, UK, pp. 141-232.

Chapman, J. L. and Resiss M. J. (2002). Ecology; Principles and Application. 2nd edition, Cambridge University Press.

Cornelius, E.W., Bani, R.J., Boateng, B.A., Egyir, I.S., Josaih, M.N., Obeng- Ofori, D., Ofosu- Anim, J. and Timpo, S.E. (2008). Postharvest Science and Technology, University of Ghana, Legon. Pp 11-137.

Cowley, R. J., Howard, D. C. and Smith, R.H. (1980). The effect of grain stability on damage caused by Prostephanus truncatus (Horn) and three other pests of stored maize. Journal of Stored Product Research, 16:7578. 
De Groote, H., Kimenju, S.C., Likhayo P., Kanampiu, F., Tefera, T., and Hellin, J. (2013). Effectiveness of hermetic systems in controlling maize storage pests in Kenya. Journal of Stored Products Research, 53: 27-36.

Denno, R. F., C., Gratton, M.A., Peterson, G. A., Langellotto, D. L. and Huberty, A.F. (2002). Bottom-up forces mediate naturalenemy impact in a phytophagous insect community. Ecology; 83: 1443-1458

Dhliwayo, T. and Pixley, K.V. (2003). Divergent selection for resistance to maize weevils in six maize populations. Crop Science, 43: 2043-2049.

Law-Ogbomo, K.E. and Enobakhare (2006). Reduction of post harvest loss caused by Sitophilus zeamais (Motsch) in three varieties of maize treated with plant products. Post Harvest Science, 1: 1-6.

GASGA (Group for Assistance on System Relating to Grain After Harvest) (1993). Technical leaflet no. I Second Edition. CTA, Postbus 380-6700, Netherlands. 12p

Golob, P. and Hodges, R.J. (1982). Study of an outbreak of Prostephanus truncatus infestation of maize. In Pro GASGA. Workshop on the larger grain borer $P$. truncatus. 24-25 February 1983. TPI, Slough. Publ.GTZ. Eschborn. 62-70pp.

Golob, P. (1988). Current status of the Larger Grain Borer, Prostephanus truncatus (Horn) in Africa. Insect Science and its Application, 9 (6): 737-745

Golob, P. (2002). Chemical, physical and cultural control of $P$. truncatus. Integrated Pest Management Revision, 7: 254-277.

Gueye, M. T., Goergen, G., Badiane, D., Hell, K. and Lamboni, L. (2008). First report on occurrence of the larger grain borer Prostephanus truncatus (Horn) (Colcoptera: Bostrichidae) in Senegal. African Entomologi; 16:309-311.

Halstead, D.G.H. (1962). External sex difference in stored products coleopteran. Bulletin of Entomological Research, 54: 119-134.

Hodges, R. J., Dunstan, W. R., Magazine, I. \& Golob, P. (1983). An outbreak of Prostephanus truncatus (Horn) in East Africa. Protection Ecologr , 5: 183-194.
Hodges, R. J. (1986). The biology and control of P. truncatus (Horn) (Coleoptera: Bostrichidae). A destructive storage pest with an increasing range. Joumal of Stored Product Resecurch. 22: 1-14.

Howard, D.C. (1984). The ability of Prostephanus truncatus to breed on different maize varieties. Proceedings of GASGA workshop on LGB. Tropical Products Institute, Slough Publication, GTZ Eschborn, 17-31.

Kankolongo, M.A., Hell, K. and Nawa. (2009). Assessment for fungal mycotoxin and insect spoilage in maize stored for human consumption in Zambia. Journal Food Science Agriculture, 89: 1366-1375.

Kossou, D.K., Bosque-Perez, N. A. and Marek J. H. (1992). Effect of shelling maize on the oviposition and development of Sitophilus zeamais (Motsch). Journal of Stored Product Research, 28 (3):187-192.

Magrath, P.A., Compton, J.A., Motte, F. F., Awuku, M. (1996). Coping with a new storage insect pest: The impact of the larger grain borer in eastern Ghana, Natural Resources Institute, UK.

Meikle, W. G., Holst, N., Scholz, D. and Markha, R. H. (1998). Simulation model of Prostephanus truncatus (Coleoptera: Bostrichidae ) in rural maize stores in the Republic of Benin Environmental Entomology, 279(1): 59-68.

Mwololo, J. K., Mugo, S. N., Tefera, T., Okori, P., Munyiri, S. W., Semagn, K., Otim, M., Beyene, Y. (2012). Resistance of tropical maize genotypes to the larger grain borer. Journal of Pesticide Science, 85:267-275.

Mwololo, J. K., Mugo, S., Okori, P., Tadele, T., Munyiri, S.W.(2010). Genetic diversity for resistance to larger grain borer in maize hybrids and open pollinated varieties in Kenya. Second RUFORUM Biennial Meeting. Uganda.

Obeng-Ofori, D. (2008). Major stored products arthropod pests. . In: Comilius, E.W. and Obeng-Ofori, D. (eds), Post-harvest Science and Technology. Smartline Publications, Accra, Ghana, 68-70.

Omondi, B.A., Nanqing, J.,Vandenberg, J., Schulthess, F. (2011). The flight activities of Prostephanus truncatus (Horn) (Coleoptera: 
Bostrichidae) and Teretrius nigrescens (Lewis) (Coleoptera: Histeridae) in Kenya. Joumal of Stored Product Research. 47:13-19.

Osipitan, A.A., Somade, A. A. and Lawal, O.A. (2008). Laboratory investigation of damage potential of larger grain borer- Prostephanus truncatus (Horn) (Coleoptera: Bostrichidae) on some dried root and tuber crops in Nigeria. Agricultural Sciences Environment and Technology Jounnal, Series A, 8(2): 181-192.

Osipitan, A.A., Akintokun, K., Odeyemi, S. and Bankole, S.O. (2011). Evaluation of damage of some food commodities by larger grain borer, Prostephanus truncatus (Horn) (Coleoptera: Bostrichidae) and microbial composition of frass induced by the insect. Archives of phytopathology and plant protections 44 (6): 537-546.

Panthenius, V.C. (1988). Storage losses in traditional maize granaries in Togo. Insect Science and its Application 9: 725-735.

Sahaf, B. Z., Moharramipour S. and Meshkatalsadat, M.H.(2008). Fumigant Toxicity of Essential oil from Vitex pseudonegundo against Tribolium castaenum (Herbst) and Sitophilus oryzae (L.). Journal of Asia-Pacific Entomology, 11(4): 175-179.

Singano, C.D, Nkhata, B.T. (2004). Data on larger grain borer insect collected from three districts in the southern region of Malawi using pheromone traps. Bvumbwe Agricultural
Research Station, Thyolo, Malawi. $7 \mathrm{pp.}$

Singano, C.D., Nkhata, B.T., Magombo, H. and Tembo, M.O. (2007). Larger grain borer monitoring and Teretrius nigrescens rearing and release for the southern region of Malawi. Bvumbwe, Agricultural Research Station, Thyolo, Malawi. $8 \mathrm{pp}$.

Stathers, T.E., Denniff, M. and Golob, P. (2008). The efficacy and persistence of diatomaceous earths admixed with commodity against four tropical stored product beetle pests. Journal of Stored Products Research, 40: 113-123.

Tefera, T., Mugo S., Likhayo P. and Beyene Y. (2011). Resistance of three-way cross experimental maize hybrids to post harvest insect pests, the larger grain borer (Prostephanus truncatus) and maize weevil (Sitophilus zeamais). International Journal Tropical Insect Science, 31 (1 and 2):3-12.

Weimerkirch, H., Ancel, A., Caloin, M., Zahariev, A., Spagiari, J., Kerstein, M. and Chastel, O. (2003). Foraging efficiency and adjustment of energy expenditure in a pelagic seabird provisioning its chick. Journal of Animal Ecology; 72: 500 -508.

Yusuf, S. R. and Ahmed, B. I. (2005). Effect of application rates of some plant materials on the control of maize weevil (Sitophilus zeamais Motsch) in stored maize. Journal of Pure and Applied Sciences, 8 (2): 180 - 187.

"Sadiku, B.T., Kemabonta, K.A., and Makanjuola, W. A.

Vigerian Journal of Entomology.

Published by the Entomological Society of Nigeria

"Iw w.esn.org.ng

ISSN: $0331-(004) 4$

lolume 33.2017

pp. $37-45$

DOI:10.36108/NJE/7102/33(0150)

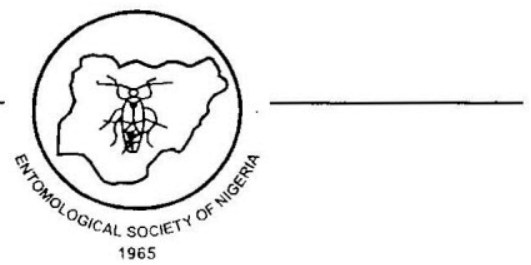

